Received: 7 February 2021 Accepted: 10 February 2021

Keywords: Holocaust; Jews; Concentration Camps; Nazis, USA

\section{Fella Feige Drut}

\author{
Des Maguire
}

Abstract: This article is the story of Fella Feige Drut, who was born in Rovno, Ukraine in 1923 and who in 1939, at the age of 16, was arrested by the Gestapo in Würzburg, Germany because she was Jewish. She survived six years in various concentration camps and work camps, eventually ending up in the Theresienstadt ghetto. Here, she gave birth to a daughter. Her ordeal and that of her close family members are reconstructed using documents from the International Tracing Service's (ITS) archive and from other sources. Unlike many of her co-religionists, whose family life ended during the Nazi years (1933-1945), Fella Feige Drut was able to live on. Her resolve manifested itself in her fight for compensation from the German government for herself and her daughter, despite the bureaucratic hurdles placed in her way, and her resolution to leave Germany and to build a new life in the USA.

\title{
Introduction
}

The purpose of this article is to demonstrate that it is still possible to develop a family tree and infuse it with snippets of family history even for Jews who were victims of the Nazi death machine in Europe. This is especially true of the Jews who lived in Western Europe. The copy of the International Tracing Service's archive, located at the Wiener Holocaust Library in London is the source of many of the documents relied on for this story. ${ }^{1}$ This is the history of a quite remarkable young woman called Fella Feige Drut whose first contact with the Gestapo (Geheime Staatspolizei) occurred at the age of 16 when she was arrested in Würzburg. ${ }^{2}$

The article will show that, from a starting point which yields very little personal information, it is possible to develop a personal narrative that has many twists and turns, and yet, is replete with human elements that are not all tragic. That starting point is Fella Feige's arrest by the Gestapo.

\section{Main Findings}

\section{Concentration Camps}

There is a very apposite German word to describe the experiences of those who were victims of the Nazis during the Holocaust. It is Leidensweg or "path of suffering". Fella Feige's journey through some of the most infamous concentration camps started in Würzburg in 1939 and it lasted till 1945. Her Gestapo files are both interesting and instructive. ${ }^{3}$ They state that:

- she was arrested on 01 September 1939 in Würzburg

- she was stateless

- she was a Catholic, although formerly Jewish

- she had been living in Dresden since 1935 and that because her father was Jewish, she was classified as a Mischling (of mixed Jewish/ Aryan blood) first grade and therefore considered a Jew. ${ }^{4}$

The latter fact is highly important for Fella Feige's future. Figure 1, which is an ITS index card, ${ }^{5}$ shows in summary form, Fella Feige's Leidensweg through various Nazis concentration camps and ghettos. It also shows that she was born on 06 April 1923 in Rovno, Poland (today Rivne, Ukraine).

In November 1939, Fella Feige was transferred from the Gestapo prison in Hof northern Bavaria to Ravensbrück concentration camp, and later in January 1942, she was sent to Flossenburg concentration camp. ${ }^{6}$ From there, she was transferred shortly afterwards to the Hellerberg work 


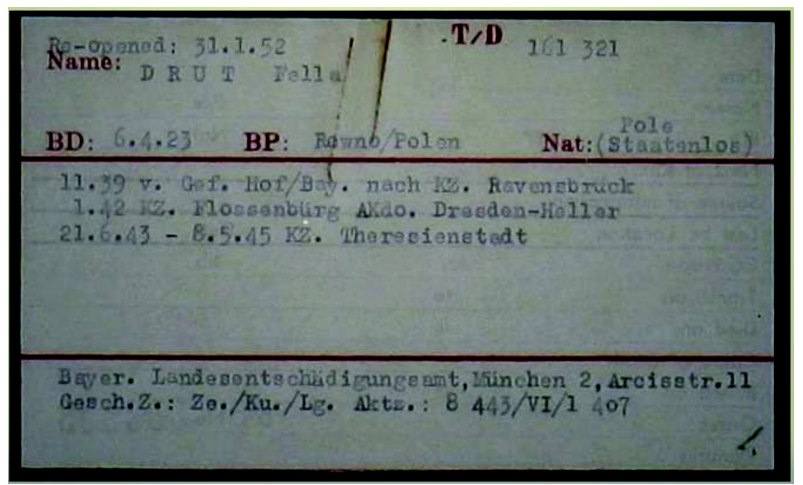

Figure 1. Fella Feige Drut's incarcerations after being arrested on 01 September 1939 for being a Jew.

camp near Dresden, ${ }^{7}$ which was a camp for Jews working in local industries. Her occupation is given as a tailor's cutter. ${ }^{8}$ The Hellerberg camp was previously an old army barracks on the outskirts of Dresden. The site was used from 20 February 1942 onwards for those working locally in the armaments industry, especially in the Zeiss-lkon establishments, as part of the Gauleiter of Saxony, Martin Mutschmann's, determination to make Dresden Judenfrei or "free of Jews". ${ }^{9}$

However, as Longerich (1994) ${ }^{10}$ and Held (2008) ${ }^{11}$ both argue, 'purifying' the German race by expelling all others was a fundamental tenet of Nazism and not subordinate to winning a war. As a result, on the evening of 02/03 March 1943, the Hellerberg camp was disbanded and all men, women and children there were sent to Auschwitz-Birkenau, apart from one. That one was Fella Feige Drut and the question is why was she spared? There were 350 people from the camp who went to Auschwitz-Birkenau and very few survived. ${ }^{12}$ There is a suggestion that 10 survived, although most were gassed immediately after arrival. ${ }^{13}$

Gryglewski in his book 'Remembrance has a face' reveals that Fella Feige Drut was not sent to Auschwitz-Birkenau because she was pregnant. This appears to be a completely implausible suggestion. Firstly, because as young children were incapable of work, they were automatically sent to the gas chambers, ${ }^{14}$ and secondly, there are some eye-witness horror stories about what happened in Auschwitz-Birkenau to babies ${ }^{15}$ newly born there. As such, it is unlikely that any suggestion of compassion by the SS (Schutzstaffel/protection unit) for Fella Feige's pregnancy or her child was relevant in this context. Instead, a more credible reason is the indecision of the Nazis regarding how to deal with Mischlinge. ${ }^{16}$ As indicated earlier, Fella Feige Drut was a half Jew; she was therefore a half Aryan and the Nazis had a great reverence for Aryan blood. In addition, the authorities were also worried about the reaction and morale of Aryan relatives at home and in the army. ${ }^{17}$

Having been spared transportation to Auschwitz-Birkenau, Fella Feige was deported on 21 June 1943 on Transport V/9 from Dresden to Theresienstadt. ${ }^{18}$ Her details on the deportation list are transcribed in Table 1:

Table 1. Transcription of Fella Feige Drut's details from the deportation list V/9.

\begin{tabular}{lllllll}
\hline Deportation Number & $1^{\text {st }}$ Name & Surname & DOB & Place of Birth & Occupation & Dresden Address \\
386 & Fella Feige & DRUT & $06 / 04 / 1923$ & Rovno & Tailor's Cutter & Konkordienstr. 68 \\
\hline
\end{tabular}

Figure 2 further reinforces the point made earlier about the importance of being a Mischling. To the right of her name there is the designation 'Gelt Jüd' which is an abbreviation for Geltungsjüde meaning considered by the Nazis as a Jew, although actually a mixed-race person.

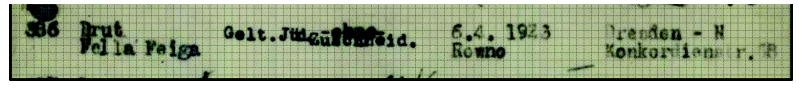

Figure $2 .^{19}$ The entry for Fella Feige Drut on deportation list V/9.

She gave birth to a daughter, Doris Tana, on 09 November 1943 in the Magdeburger barracks in the Theresienstadt ghetto. ${ }^{20}$ Despite terrible privations which have been well-documented in eye-witness statements ${ }^{21}$ and the fact that the Nazis had built four gas chambers in 
Theresienstadt with the intention of liquidating all of its inmates, both she and her daughter survived and were in the ghetto when it was liberated by the Red Army on 09 May 1945. They were released on 21 June 1945 and returned to Bamberg in Germany. ${ }^{22}$

At this point in the narrative available information about Fella Feige Drut's family tree is sparse (see Figure 3).

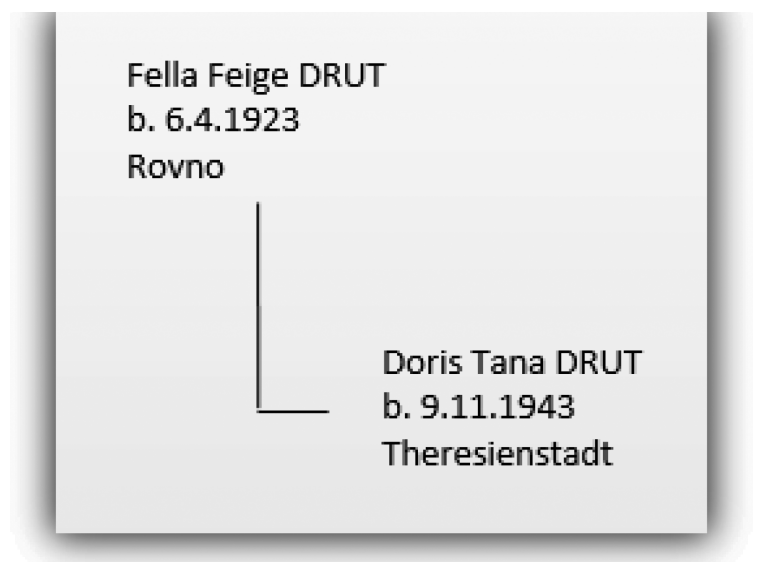

Figure 3. Fella Feige Drut's family tree.

\section{Family Relationships}

Although the ITS contains a great deal of family information, the links between documents do not always exist, so family relationships are not easy to establish from this source alone. As such, it is sometimes necessary to utilise other sources of information. The case of Fella Feige Drut is a good example of this problem. A name search in the ITS system on both Fella Feige and Doris Tana produces many documents (44), ${ }^{23}$ but in order to be certain about her family, it is judicious to start with the information in: Memorial Book: Jews in Dresden: deported, murdered, disappeared: $1933-1945 .^{24}$

There is a lot of very valuable family history information here, all of which needs to be confirmed by another source. It is recorded that Fella's father was Sjoma Schija Drut who was born 14 May 1891 in Meshduretschje, then part of the Tsarist Empire, and now called, Velyki Mezhyrichi, in the Ukraine. ${ }^{25}$ In 1897 there were 2,107 Jews in this village, which amounted to 67\% of the total population. They were predominantly Hasidic Jews. ${ }^{26}$ His wife was Barbara Margaret Ringelmann and they had three children together: Fella Feige, Manfred and Max. According to the entry, Sjoma was a Kapellmeister, that is, a band or orchestra leader. He was arrested in Dresden on 09 November 1938, the date of Kristallnacht "night of the broken glass" when many Jewish businesses were broken into and plundered by mobs, many synagogues were set on fire, and prominent Jews were arrested and sent to concentration camps. ${ }^{27}$ From Dresden, he was sent to Dachau where he was murdered. Fella Feige Drut, who was also living in Dresden and working as a tailor's cutter, left in 1938 with her mother and went to Würzburg, where she was arrested by the Gestapo.

Another interesting point in this entry, which may be more difficult to confirm, is that the memorial Book suggests that Fella was 'married' to Atonas Daboff, who was born 28 January 1915 in Plovdiv, Bulgaria, and that he was the father of Doris Tana. It further states that he perished during the Holocaust.

There are many documents referring to the Drut family in the ITS archives. They confirm that Fella Feige's father, Sjoma Schija Drut, was indeed a bandmaster, born on 14 May 1891 in Meschirjetsche, Russia. ${ }^{28}$ The different spellings of the town he was born in reflect the mixture of peoples and ruling authorities in that part of Central Europe at that time. So, the place has a name in Russian, Polish, Ukrainian, German, Yiddish and Hebrew. ${ }^{29}$ The ITS document reveals that Sjoma's father was Icko Gersh Drut and that his mother's name was Feige Listek. There is a marriage record for Sjoma and Barbara Ringelmann in Ancestry.com. ${ }^{30}$ This shows that the marriage took place on 26 March 1920 in Hamburg where they were both living. It further reveals that Barbara Margareta Ringelmann was born on 19 September 1893 in Würzburg, and that her parents were Martin Ringelmann and Klara Drechsler. The only curiosity on the marriage certificate for Sjoma and Barbara, is that Barbara's religion is given as Jewish (mosaisch), which definitely could not have been her birth religion, otherwise Fella Feige would have been classified as Jewish, rather than as a Mischling first grade. 
Fella Feige also had two brothers: Itzaak (Max) Drut who was born in Danzig (today Gdansk, Poland) on 19 June $1926^{31}$ and Abraham Manfred Drut who was born 13 July 1927 in Würzburg. ${ }^{32}$ There is very little in the ITS archives relating to Itzaak Drut apart from one document that suggests that he emigrated from Schweinfurt, Germany to the USA with his mother around $1950 .{ }^{33}$ There is no confirmation of this in other documents. However, there is some very interesting material in the ITS archives regarding Abraham Manfred Drut. The International Red Cross records reveal that he was arrested in Bamberg, Germany before 29 October 1945 and sentenced to 10 years imprisonment for the possession of weapons. ${ }^{34}$ This is further evidenced by a later document from the police in Zweibrücken, Germany dated 24 January 1967 which states that on that date, he was in prison in that city. ${ }^{35}$

Fella Feige's family tree, augmented by information from the ITS archives and other sources, is shown in Figure 4.

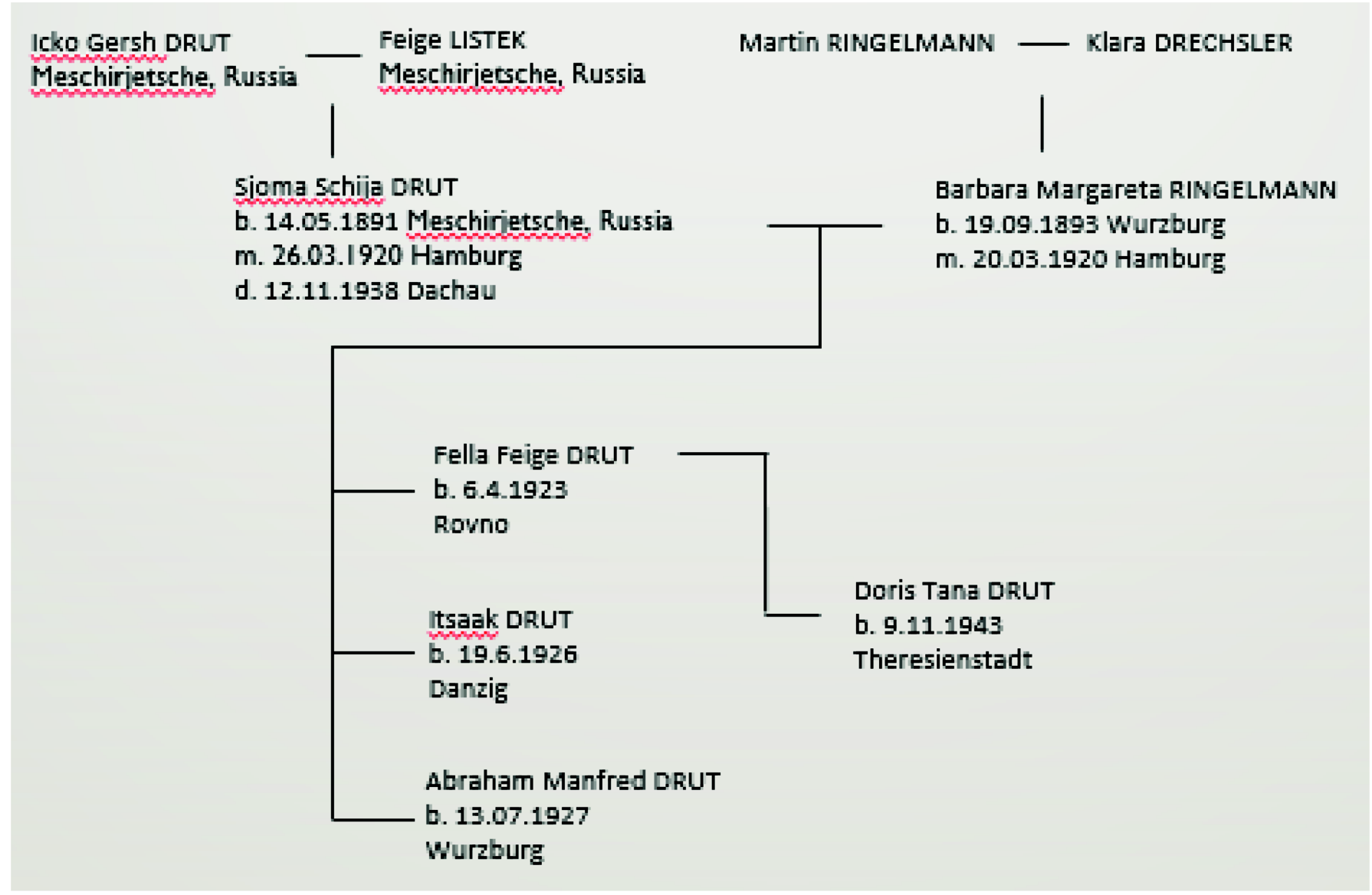

Figure 4. Fella Feige Drut's family tree in 1945.

\section{Post War Struggle for Compensation and emigration}

After her release from the Theresienstadt ghetto on 21 June 1945, Fella Feige lived at Memmelsdorferstr. 57, Bamberg, Germany with her mother Barbara and her daughter Doris. ${ }^{36}$ Her aims from 1949 onwards appear to have been to seek compensation for herself and Doris for their incarceration and to emigrate away from Germany. She wrote an eloquent letter dated 06 December 1949 to the ITS in which she listed all of the locations where she had been incarcerated on "rassistischen Gründen" (because of her race) and pleaded her case because the compensation was "dringend benötige" (urgently required) ${ }^{37}$ In response, the ITS asked Fella Feige to fill in the necessary forms to request compensation for both her own and her daughter's incarceration by the Nazis. This Fella Feige did giving the following information: ${ }^{38}$

- She was stateless, single and a tailor's assistant

- She was in Ravensbrück from 30 November 1939, and her identification number was 2439

- She was in Dresden from January 1942 
- She was in Theresienstadt from 21 June 1943, deported on transport V/9 out of Dresden.

- She was liberated on 09 May 1945 and released on 21 June 1945.

She submitted a similar form for her daughter Doris. ${ }^{39}$ Both requests were denied on 27 January 1950. The reason given was: "The documents of conc. Camp Theresienstadt are incomplete." ${ }^{\prime 40}$ Subsequently, Fella submitted a second request for compensation on 24 April 1950 giving additional details about her incarceration in the prison at Hof in Bavaria and at the Flossenberg concentration camp. In addition, she added details about the time she spent at the forced labour camp at Hellerberg near Dresden. ${ }^{41}$ There is no evidence that this was successful either, and in fact, Fella Feige received a letter dated 06 June 1951 regarding Doris, which stated that the documents that she provided and which were issued by the Czech Welfare Ministry in October 1945, were inadmissible. The ITS informed her that only original concentration camp documents were acceptable as proof of incarceration. ${ }^{42}$

Fella's experience appears to show that the onus was on the victim of the Holocaust to prove their victimhood in order to receive compensation, and that certain evidence, such as being named on a Gestapo list (here, for transportation V/9) or shown to be a concentration camp survivor (here, in Czech Welfare Ministry documents), was not deemed sufficient proof to warrant a certificate of incarceration. A good, further example, of the bureaucratic hurdles placed in front of those victims of Nazi oppression is the case of her father, Sjoma Schija Drut. His wife, Barbara Drut, first made an application for a death certificate for him on 05 January 1950,4312 years after his death in 1938. A second application for his death certificate and a confirmation of incarceration was made on 22 January $1962 .{ }^{44}$ The response to this request on 28 March $1962^{45}$ asks for his Dachau prisoner number and states that there is no proof of his death. As this was 24 years after he perished in Dachau, the compensation authorities were asking for the impossible. How could relatives prove that someone perished, and how would they know his Dachau prisoner number? The ultimate response to Barbara's second application was a form dated 30 July $1969 .{ }^{46}$ On this form was a large red stamp on it with the words: "Überprüfung: negative" (investigation negative).

Fella Feige emigrated to the USA with her daughter Doris on 24 April 1950 on the US Navy Ship, "General RM Blatchford", travelling from Bremerhaven to New York. On the ship's manifest, their nationality is listed as Polish. ${ }^{47}$ Her initial address in New York is given as 15 Park Row, New York 7. ${ }^{48}$ Her mother, Barbara, emigrated on 30 July 1950 from Bremerhaven to Boston, USA on the "General Muir". Her initial destination address was 1526 North Market Avenue, Canton, Ohio. ${ }^{49}$ The fact that Barbara went to Canton, Ohio and that Fella and Doris went to New York suggests that they all wanted to leave Germany for the USA as soon as possible and that they took the best options offered to them at the time.

Answers to questions regarding Isaak Drut are much more opaque. As mentioned earlier, information in the ITS system suggests that he travelled to the USA with his mother. ${ }^{50}$ However, he does not appear on the passenger manifest of the General Muir. ${ }^{51}$ What is also curious is that on her application for US naturalisation, Barbara states that she only has two children: Fella Feige and Abraham. ${ }^{52}$ There are no immigration records that show that Isaak Drut entered the USA. Documentary evidence confirms that he was born in Danzig on 13 October $1925,{ }^{53}$ however there is also a record of a death in Dresden 23 March 1926 of a baby named Icko Gersch Drut, aged 5 months. ${ }^{54}$ As "Icko Gersch" was the name of Fella's grandfather, and "Icko" is another name for Isaak, this record suggests that Isaak Drut may have died as a baby.

\section{Life in the USA}

Barbara Drut's application for US naturalisation was made on 11 March 1957 in Brunswick, Georgia, USA. ${ }^{55}$ Either she joined her daughter and her grand-daughter there or they joined her because Fella Feige's application for naturalisation, made on 10 August 1954, was also submitted in Brunswick. ${ }^{56}$ It makes very interesting reading as it reveals that Fella Feige married Wade Roy Evans, who was from Georgia, on 01 January 1951, and that they had a child together called Barbara Ann on 24 February 1954.

Fella Feige's naturalisation application also sheds some light on the identity Doris Tana's father and confirms the suggestion made in the "Memorial Book: Jews in Dresden: deported, murdered, disappeared: 1933-1945". ${ }^{57}$ Fella Feige recorded her name as Phyllis Fella Evans, formerly Daboff, née Drut. It is possible that she and Atonas went through some sort of marriage ceremony at the Hellerberg Labour Camp near Dresden. Atonas Daboff, who was born on 28 January 1915 in Plovdiv, Bulgaria, ${ }^{58}$ was a student in Dresden when he was arrested because he was Jewish and sent to the Hellerberg Labour Camp. The naturalisation documents state that he was in the Theresienstadt ghetto from April 1943 until July 1943, ${ }^{59}$ although there is no further proof of this. What is clear, however, is that he was sent to Auschwitz-Birkenau in July 1943 and perished there. ${ }^{60}$ A further indication that he was Doris Tana's father is that a request for a Certificate of Incarceration for him was raised by the American Federation of Jews from Central Europe on behalf of Fella Feige Drut of New York. ${ }^{61}$ 
Fella Feige's marriage to Wade Roy Evans (1928-1988) did not last, and she married George Gettinger I (1921-1996) in Brunswick, Georgia on 22 December 1968. ${ }^{62}$ Her mother, Barbara Drut, died on 17 September 1972 in Grady, Georgia aged 79. ${ }^{63}$ Fella Feige died on 13 November 1991, Brunswick, Georgia aged 68. ${ }^{64}$ Figure 7 shows her gravestone in Palmetto cemetery, Brunswick, Georgia, USA. ${ }^{65}$

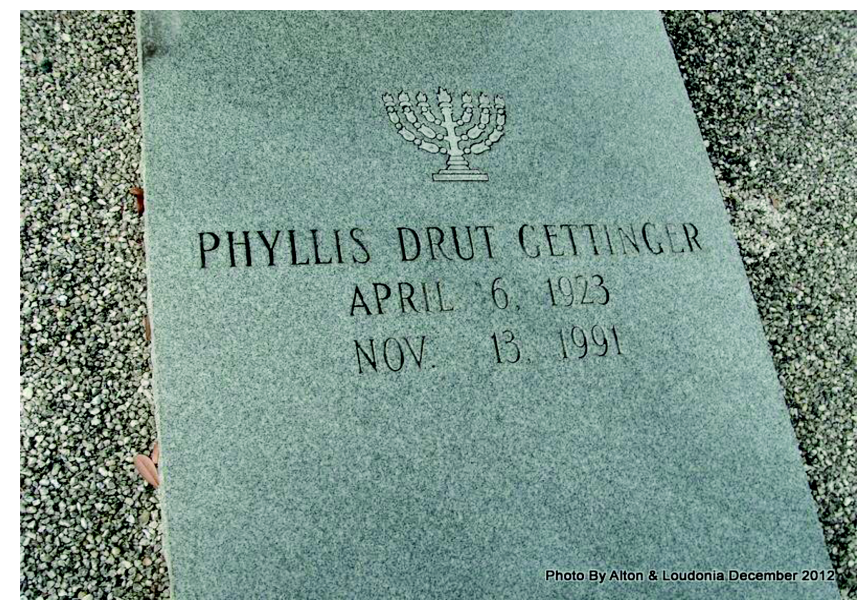

Figure 5. Fella Feige Drut's Gravestone.

Her daughter, Doris Tana, here shown as a 17 year old in her high school year book in Georgia (see Figure 6), married Richard Alan Baker in Glynn County, Georgia on 22 December $1961^{66}$ and with him she had two sons. ${ }^{67}$

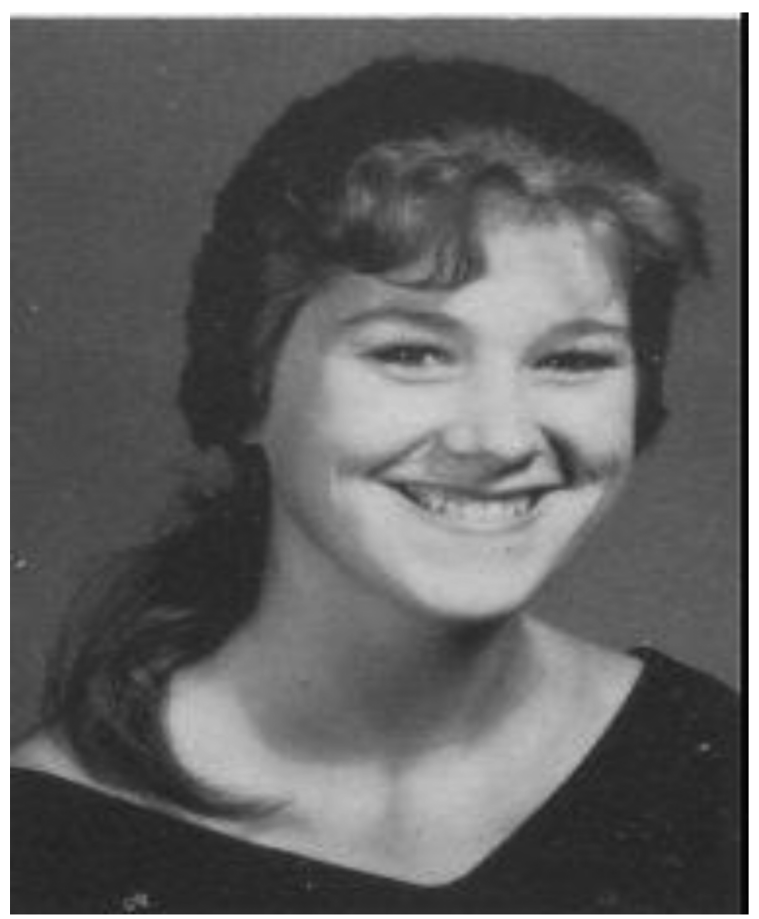

Figure $6 .^{68}$ Doris Evans, Brunswick, Georgia, USA 1961.

She died aged 69 on 05 December 2012. What is ironic, is that the US Social Security Death Index $1935-2014^{69}$ shows that, at the time of her death, she owned four properties and died on Saint Simons Island, ${ }^{70}$ a place described as a resort and one of Georgia's 'golden islands'.71 So, perhaps, she was born in hell and died in paradise. 


\section{Conclusion}

This article demonstrates that, by focusing on an individual victim of the Nazi regime (1933-45), it is possible using the documentation in the ITS archives and other sources to develop a family tree for a Jewish person that can be followed across Central Europe. However, it is worth noting that Fella Feige Drut was an exception, inasmuch as her family line was not extinguished during those horrific years. Yet, she too was a victim. She was arrested by the Gestapo as a 16-year-old. She spent six years in various concentration camps and labour camps, during which time she gave birth to a child. Her father was murdered in Dachau and the father of her child was murdered in Auschwitz. Her brother became a felon, and ultimately, she, her child and her mother left the area they had lived in and made a new life in a different country, and with a different language.

That Fella Feige Drut succeeded against the odds and made a new life for herself and her daughter in the USA is a testament to her resolve and her resilience. She deserves our respect.

\section{Reference}

1 The International Tracing Service via the copy at the Wiener Holocaust Library, Russell Square, London.

2 Gestapo Arrest Card Index. 15 September 19394. DRUT, Fella Feige. ITS, Central Name Index, Document Id: 123304733_0_1.

3 Gestapo Files. 1939. Würzburg. DRUT, Fella Feige. ITS, Central Name Index, Document Ids: 12304728_0_1, 12304732_0_1, 12304733_0_1.

4 Gestapo Files. 1939. Würzburg. DRUT, Fella Feige. ITS, Central Name Index, Document Id: 12304733_0_1.

5 Index Card. DRUT, Fella Feige. ITS, Central Name Index, Document Ids: 87337781_0_1.

6 Index Card. DRUT, Fella Feige. ITS, Central Name Index, Document Ids: 87337781 0_1.

7 Gryglewski, Marcus. (1998) The face of National Socialist persecution of the Jews in Dresden 1933-1945'. In: Haase, Norbert, Jersch-Wenzel, Stefi, Simon, Hermann (HG). Bearbeitet von Marcus Gryglewski. (1998) Die Erinnerung hat ein Gesicht/ Rememberance has a face. Leipzig: Gustav Kiepenheuer Verlag GmbH. P. 121.

8 Index Card. DRUT, Fella Feige. ITS, Central Name Index, Document Ids: 87337781_0_1, 87337782.

9 Gryglewski, op. cit. p. 120

10 Longerich, Peter. (1994) Die Wannsee-Konferenz vom 20. Januar 1942 Planung und Beginn des Genozids an den europäischen Juden The Wannsee Conference of 20 January 1942. The planning and commencement of the genocide of European Jewry. https://scholar.google.de: accessed 27 October 2017. p. 4.

11 Held, Steffen. (2008) Die Leipziger Stadtverwaltung und die Deportation der Juden im NSStaat, Leipzig/The city administration in Leipzig and the deportation of Jews in the Nazi state. Stadtgeschichtliches Museum. http://www.qucosa.de/fileadmin/ data/qucosa/documents/7155/Deportationen_Leipzig.pdf: accessed 23 November 2017. p. 5.

12 Yad Vashem. Transport from Dresden,Dresden (Dresden Bautzen),Saxony, Germany to Auschwitz Birkenau, Extermination Camp,Poland on 02/03/1943. https://deporta tion.yadvashem.org/index.html?language $=$ en\&itemld=10978717\&ind $=-1$ : accessed 06 November 2020.

13 Stiftung Sächsische Gedenkstätten/Memorial Places in Saxony Charity. Hellerberg camp for Jews. https://en.stsg.de/cms/node/815: accessed 06 April 2018.

14 Memorial and Museum, Auschwitz-Birkenau. Jewish Children. http://auschwitz.org/ en/history/fate-of-children/jewish-children: accessed 06 November 2020.

15 Moravitz, Emmi. Eyewitness testimony, Doc 1656, P.III.h. (Auschwitz) No. 665, translated from the German by Des Maguire on behalf of the Wiener Library. pp. 2-9.

16 Noakes, Jeremy. (1989) The Development of Nazi policy towards the GermanJewish "Mischlinge"1933-1945'. The Leo Baeck Institute Year Book. 34(1). Pp.291354. https://doi.org/10.1093/leobaeck/34.1.291: accessed 04 November 2017. p. 313. And. Gerlach, Christian. (1998) The Wannsee Conference, the Fate of the German Jews, and Hitler's Decision in in Principle to Exterminate All European Jews. The Journal of Modern History. http://www. uchicago.edu/t-and-c: accessed 05 December 2017. p. 801.

17 Noakes, Ibid. p. 313. And. Gerlach, Ibid. p. 761.

18 Gestapo Deportation List, V/9, 21 June 1943, Dresden to Theresienstadt. ITS, Search All Archive Units, Document Id: 11197479

19 Gestapo Deportation List, V/9, 21 June 1943, Dresden to Theresienstadt. ITS, Search All Archive Units, Document Id: 11197479_0_1.
20 Index Card. DRUT, daughter. ITS, Central Name Index, Document Ids: 87721584_0_1, 87721586_0_1.

21 Anonymous. Eyewitness Testimony, Doc 1656, P.II.h. No. 581. (Theresienstadt) translated from the German by Des Maguire on behalf of the Wiener Holocaust Library. Anonymous. Eyewitness Testimony, Doc 1656, P.III.h. No. 493, p. 10 translated from the German by Des Maguire on behalf of the Wiener Holocaust Library.

22 Request for Certification of Incarceration. DRUT, Fella. ITS, Central Name Index, Document Ids: 87337804_0_1.

23 Maguire, Des. (2018) What is the value of the International Tracing Service (ITS) to family historians? A research study based on the deportation of Jews from Dresden to Theresienstadt (1942 to 1944). Unpublished MSc dissertation. P. 45.

24 Gesellschaft für Christlich-Jüdische Zusammenarbeit Dresden. (2006) Buch der Erinnerung: Juden in Dresden: deportiert, ermordet, verschollen: 1933-1945/ Memorial Book: Jews in Dresden: deported, murdered, disappeared: 1933-1945. Dresden: Richter.

25 JewishGen. JewishGen Communities Database. https://www.jewishgen.org/ Communities/jgcd.php: accessed 28 December 2020.

26 History of the Jewish Communities in the Ukraine. Mezhyrichi. http://jewua.org/ mezhyrichi/: accessed 28 December 2020.

27 United States Holocaust Memorial Museum (USHMM). Kristallnacht. https://ency clopedia.ushmm.org/content/en/article/kristallnacht: accessed 26 December 2020.

28 Request for Certification of Incarceration. DRUT, Schija. ITS, Central Name Index, Document Ids: 87046562_0_1.

29 JewishGen. op. cit.

30 Marriages (PR) Germany. Hamburg. 26 March 1920. DRUT, Schija and RINGELMANN, Barbara Margareta. https://www.ancestry.co.uk/: accessed 28 December 2020.

31 Card Index. 12 September 1966. DRUT, Itzaak. ITS, Central Name Index, Document Id: 82535824_0_1.

32 Information Request. 8 March 1967. DRUT, Abraham Manfred, ITS, Central Name Index, Document Id: 87739487_0_1.

33 Information Request. 22 August 1966. DRUT, Itzaak, ITS, Central Name Index Document Id: 82535831_0_1.

34 Displaced Persons Registration Records. 08 March 1967. DRUT, Abraham. ITS, Central Name Index, Document Id: 87739487_0_1.

35 Polizeidirektion Zweibrucken. 24 January 1967. DRUT, Abraham. ITS, Central Name Index, Document Id: 87739484 0 1.

36 Registration of Foreigners and German Persecutees, 1939-1947. 01 April 1947. DRUT, Fella. https://www.ancestry.co.uk/: accessed 30 December 2020.

37 Letter request for compensation to ITS, Bad Arolsen, Germany. 06 December 1949. DRUT, Fella Feige. ITS, Central Name Index, Document Id: 87721592_0_1, 87721592_0_2, 87721592_0_3.

38 Certificate Request. 14 December 1949. DRUT, Fella Feige. Bad Arolsen, Germany. ITS, Central Name Index, Document Id: 87337804_0_1.

39 Certificate Request. 14 December 1949. DRUT, Doris Tana. Bad Arolsen, Germany. ITS, Central Name Index, Document Id: 87721591_0_1.

40 ITS Reply. 27 February 1950. DRUT, Fella Feige. Bad Arolsen, Germany. ITS, Central Name Index, Document Id: 87337801_0_1. ITS Reply. 27 February 1950. DRUT, Tana. Bad Arolsen, Germany. ITS, Central Name Index, Document Id: 87721602_0_1.

41 Certificate Request. 24 April 1950. DRUT, Fella Feige. Bad Arolsen, Germany. ITS, Central Name Index, Document Id: 87337800_0_1. 
42 ITS Reply. 06 June 1951. DRUT, Fella Feige. Bad Arolsen, Germany. ITS, Central Name Index, Document Id: 87721601_0_1.

43 Certificate Request. 05 January 1950. DRUT, Sjoma Schima. Bad Arolsen, Germany. ITS, Central Name Index, Document Id: 87046572_0_1.

44 Certificate Request. 22 January 1962. DRUT, Sjoma Schima. Bad Arolsen, Germany. ITS, Central Name Index, Document Id: 87046562 o 1.

45 Letter from the Compensation Authority, Hildesheim, Germany. 28 March 1962 DRUT, Sjoma Schima. Bad Arolsen, Germany. ITS, Central Name Index, Document Id: 87046572_0_1.

46 Certificate Request. 30 July 1963. DRUT, Sjoma Schima. Bad Arolsen, Germany. ITS, Central Name Index, Document Id: 87046563_0_1.

47 Manifest of In-bound Passengers (Aliens). USA. New York. 01 May 1950. USNS General R. M. Blatchford. Manifest No. 162. https://www.ancestry.co.uk/: accessed 01 January 2021.

48 ITS. 27 January 1967. Letter to the United HIAS Services, Geneva, Switzerland for DRUT, Abraham. ITS, Central Name Index, Document Id: 87337791_0_1.

49 Op. cit.

50 ITS. 22 August 1966. Letter to the United HIAS Services, Geneva, Switzerland re. DRUT, Isaak. ITS, Central Name Index, Document Id: 82535831_0_1.

51 Manifest of In-bound Passengers (Aliens). USA. Boston. 09 August 1950. USNS General C. H. Muir Manifest No. 5. https://www.ancestry.co.uk/: accessed 01 January 2021.

52 Naturalisation Records. USA. Georgia. 11 March 1957. DRUT, Barbara. Petition Number 255. https://www.ancestry.co.uk/: accessed 02 January 2021.

53 Births (CR) Germany. Danzig, Fischmarkt 3. 13 October 1925. DRUT. https://www jewishgen.org/: 0 January 2021.

54 Death Certificates. Germany. Dresden, Saxony. 23 March 1926. DRUT, Icko Gersch. No. 316. https://www.ancestry.co.uk/: accessed 02 January 2021.

55 Naturalisation Records. USA. Georgia. 11 March 1957. DRUT, Barbara. Petition Number 255. https://www.ancestry.co.uk/: accessed 02 January 2021.

56 Naturalisation Records. USA. Georgia. 10 August 1954. EVANS, Fella Phyllis. Petition Number 217. https://www.ancestry.co.uk/: accessed 02 January 2021.

57 Gesellschaft für Christlich-Jüdische Zusammenarbeit Dresden. (2006) Buch der Erinnerung: Juden in Dresden: deportiert, ermordet, verschollen: 1933-1945/ Memorial Book: Jews in Dresden: deported, murdered, disappeared: 1933-1945. Dresden: Richter.

58 Certificate Request. 20 June 1950. DABOFF, Atanas. Bad Arolsen, Germany. ITS, Central Name Index, Document Id: 99091227_0_1.
59 Certificate Request. 20 June 1950. DABOFF, Atanas. Bad Arolsen, Germany. ITS, Central Name Index, Document Id: 99091227_0_1.

60 Certificate Request. 20 June 1950. DABOFF, Atanas. Bad Arolsen, Germany. ITS, Central Name Index, Document Id: 99091227_0_1.

61 Certificate Request. 20 June 1950. DABOFF, Atanas. Bad Arolsen, Germany. ITS Central Name Index, Document Id: 99091227 0 1.

62 Marriage USA. Glynn County, Georgia. 22 December 1968. GETTINGER 1, George and EVANS, Phyllis Feige Drut. Johnson Family Tree. https://www.ancestry.co.uk/ family-tree/person/tree/90657699/person/412184102153/facts: accessed 31 March 2021.

63 Death Index (CR) Grady, Georgia, USA. 13 November 1991. GETTINGER, Phyllis D. Indexes of Vital Records for Georgia: Deaths, 1919-1998; Certificate Number: 030515. https://www.ancestry.co.uk/: accessed 02 January 2021.

64 Death Index (CR) Glynn, Georgia, USA. 17 September 1972. DRUT, Betty R. Indexes of Vital Records for Georgia: Deaths, 1919-1998; Certificate Number: 030515. https://www.ancestry.co.uk/: accessed 02 January 2021.

65 Monumental Inscriptions. USA. Palmetto Cemetery, Brunswick, Georgia. 12 November 1991. https://www.findagrave.com/memorial/35556592/: accessed 03 January 2021.

66 Marriages (CR) USA. Glynn County, Georgia. 22 December 1961. BAKER, Richard Alan and DRUT, Doris Tana. Marriage Index-Glynn \& Surrounding Counties, Georgia, Book K, p. 171. https://www.ancestry.co.uk/: accessed 02 January 2021

67 Birth Index (CR) USA. Hennepin, Minnesota. 28 October 1962. Baker, CA. https:// www.ancestry.co.uk/: accessed 02 January 2021. Birth Index (CR) USA. Hennepin, Minnesota. 07 May 1964. Baker, CB. https://www.ancestry.co.uk/: accessed 02 January 2021.

68 Images. Photograph. Daughter DRUT. US School Yearbooks 1900-1999, Glynn Academy. https://www.ancestry.co.uk/: accessed 02 January 2021.

69 Index to Public Records, USA. 1994-2019. BAKER, Doris Tana. https://www.ancestry. co.uk/: accessed 02 January 2021

70 Death Index, Georgia, USA. 05 December 2012. BAKER, Doris T. Social Security Death Index, 1935-2014. Social Security Number: 256-64-2017. https://www.ances try.co.uk/: accessed 02 January 2021.

71 Golden Isles Georgia. St Simons Island. https://www.goldenisles.com/discover/stsimons-island/: accessed 06 January 2021.

\section{ABOUT THE AUTHOR}

The author is a Glasgow born Scot who was educated at universities in both Scotland and England. He has a M.Sc. in Genealogy, Heraldry and Paleography from the University of Strathclyde. He spent most of his working life developing software for large UK and US companies, and today he is an enthusiastic, volunteer translator (German into English) for the Wiener Holocaust Library in London. 